\title{
Dimensions of Earnings Management in Transportation Service Companies in Indonesia
}

\author{
Abdul Khalik ${ }^{{ }^{*}}$ and Sylvia ${ }^{2}$ \\ ${ }^{1,2}$ Institut Teknologi dan Bisnis Nobel Indonesia, Makassar, South Sulawesi, Indonesia \\ Email Address: \\ khalik@stienobel-indonesia.ac.id; sylvia.sjarlis2013@gmail.com
}

\begin{abstract}
This study examines accounting conservatism, leverage, litigation risk, and financial distress on earnings management. This type of research includes causal research using quantitative methods. The object of this research is a company that publishes audited financial reports and publishes them on the Indonesia Stock Exchange (IDX) for the 20172020 period. The population of transportation service companies based on the factbook of the Indonesia Stock Exchange in 2020 in 42 companies. In this study, the sampling technique used is purposive sampling. This study uses secondary data collected through the Indonesian stock exchange website and analyzed using Multiple Regression Analysis with the Ordinary Least Square model using the Eviews Version 12 software. The results found that accounting conservatism and leverage significantly affected earnings management. Meanwhile, litigation risk and financial distress have no significant effect on earnings management.
\end{abstract}

Keywords: Accounting Conservatism, Leverage, Litigation Risk, Financial Distress, Earnings Management.

Abstrak: Penelitian ini bertujuan untuk menguji konservatisme akuntansi, leverage, risiko ligitasi dan financial distress terhadap manajemen laba. Jenis penelitian ini termasuk penelitian kausal dengan menggunakan metode kuantitatif. Objek penelitian ini adalah perusahaan yang menerbitkan laporan keuangan auditan dan mempublikasikannya di Bursa Efek Indonesia (BEI) periode tahun 2017-2020. Populasi perusahaan jasa transportasi berdasarkan factbook Bursa Efek Indonesia tahun 2020 yaitusebanyak 42 perusahaan. Dalam penelitian ini teknik sampling yang digunakan adalah sampling purposive. Penelitian ini menggunakan data sekunder yang dikumpulkan melalui website bursa efek Indonesia dan dianalisis menggunakan Analisis Regresi Berganda dengan model Ordinary Least Square menggunakan bantuan software Eviews Versi 12. Hasil penelitian menemukan bahwa konservatisme akuntansi dan leverage berpengaruh signifikan terhadap manajemen laba. Sedangkan risiko ligitasi dan financial distress tidak berpengaruh signifikan terhadap manajemen laba.

Kata Kunci: Konservatisme Akuntansi, Leverage, Risiko Ligitasi, financial distress, Manajemen Laba. 


\section{INTRODUCTION}

Currently, the impact of globalization is increasingly complex, affecting the increase in the economic growth of a country so that it requires support from the development of the business world (Cavanagh, 2004). Every business requires additional capital from outside the business for its survival. This has logical consequences for the emergence of intense competition between companies to compete to make investors interested in investing their capital (Mügge, 2010). In this case, the company must demonstrate excellent and healthy practices in providing information in the company's financial statements and avoid ways to generate quick profits by prioritizing the company's survival and the interests of stakeholders in a company (Ahmad et al., 2018).

Each company's financial statements have specific criteria that align with established policies (Amin and Anwar, 2020). State-Owned Enterprises are companies whose shares are owned mainly by the public through the stock exchange. The company is required to present its financial statements following the requirements set by the competent organization in Indonesia, namely the OJK (Financial Services Authority). Submission of this financial statement information must be made to meet the needs of external and internal parties (Sriwedari, 2012). The purpose of financial statements is to provide helpful information to assess management's ability to use resources effectively to achieve the company's main objectives (Pongoh, 2013). The financial statements consist of statements of financial position, income statements, statements of changes in equity, statements of cash flows, and notes to financial statements. In general, all financial statements are essential and needed in decision-making. However, most users of financial statements are more focused on the profit information contained in the income statement without paying attention to the procedures used to generate the profit or loss (Mahardini and Juwita, 2018).

The income statement contains profit information that is useful for users of financial statement information to determine the ability and financial performance of the company. The income statement provides the information needed by shareholders and potential investors to invest their funds (Rahim et al., 2020). The income statement is a report that measures the success of the company's operations over a certain period. Profit information in financial statements is the leading information in making investment decisions (Arsyad et al., 2021). Earnings information is often the target of engineering through opportunistic actions of management to maximize their satisfaction in manipulating financial statements to attract potential investors (Mahardini and Juwita, 2018).

Until now, financial reports have become a central issue as a source of manipulation of information that can harm parties with interest in the company (Hutton et al., 2009). Such self-interested actions are carried out by choosing specific accounting policies (Hasanuddin et al., 2021). So that profits can be regulated, increased, or decreased according to their wishes (Octaviany, 2017). Earnings management is used to influence the income level at a particular time for the benefit of management and stakeholders (Manggau, 2017). Earnings management occurs when managers use their judgment in financial reporting and transaction structures to modify financial statements. When management is not successful in achieving its profit target, management will modify its reporting by selecting and applying accounting methods that can show better profit achievement to show good company performance. 
Recently, an exciting earnings management issue is the service company Garuda Indonesia, which manipulated the 2018 financial statements. This issue was finally known to the public in April 2019 because it not only covered the previous year's losses but also generated a net profit of Rp 11.33 billion or US\$ 8.0984 million. Fortunately, the company is polished. The violation in this financial report began with a cooperation agreement worth 3.41 trillion rupiahs reached with PT Mahata Aero Technology in 2018, and a net profit was obtained. If there is no record of agreement revenue, the company must suffer a loss (www.cnnindonesia.com, 2019). Earnings management is suspected to arise or be carried out by managers or financial statement preparers in the financial reporting process of a company because they expect a benefit from these actions. Earnings management is interesting to study because it can describe the behavior of managers in reporting their business activities in a certain period, namely the possibility of the emergence of specific motivations that encourage them to regulate the reported financial data.

The dimensions of earnings management in this study include accounting conservatism, Leverage, litigation risk, and financial distress. The principle of conservatism is a principle which implies that the lowest value of assets and income and the highest value of liabilities and expenses should be selected for reporting (Utama and Titik, 2018). Therefore, the principle of conservatism requires that accountants display a generally pessimistic attitude when choosing accounting techniques for financial reporting.

Conservatism in accounting leads to higher quality returns because this principle prevents companies from overestimating profits and helps users of financial statements by presenting unbiased, overpriced profits and assets (Alfin et al., 2020). The results in the financial statements can explain a company's performance because performance is one of the crucial factors that indicate the effectiveness and efficiency of an organization in achieving its goals. The implication of a conservative approach is the choice of a lowerincome and asset accounting method or a higher statement of expenses and liabilities (Beatty et al., 2008).

The choice of a conservative method in financial statements makes managers think more carefully and choose to manage earnings with a pattern of lowering profits (income decreasing). High conservative accounting in making financial reports will hinder management in increasing retained earnings (Indriani and Amalia, 2019). The research results from (Alfin et al., 2020) and Gojaya et al., 2020) state that accounting conservatism affects earnings management. While the results of research from (Delhosh \& Sadeghi, 2017) and (Ongki and Pangestu, 2018) state that accounting conservatism does not affect earnings management.

The next factor is Leverage, a loan provided to the company, while the interest charged is based on the lender's assessment of the company's risk (Firnanti, 2017). Leverage is the level of securities with debt used in a company's capital structure. Leverage is a ratio used to measure how the company is financed by debt (Fantazzini and Figini, 2009). Acceleration of maturity increased interest rates, and renegotiation of debt periods are consequences that can occur if the company violates the debt contract (Hasty \& Herawaty, 2017). Debt can improve earnings management when companies want to reduce the possibility of violating debt agreements and increase the company's bargaining position during debt negotiations (Utari and Sari, 2016).

Leverage shows how much the company's assets are financed by debt which can be measured by comparing total debt with total assets. Financial Leverage is the use of sources 
of funds that have a fixed burden, hoping that it will provide greater additional profits so that shareholder profits increase (Sutama and Lisa, 2018). Companies with large debts tend to violate debt agreements compared to companies with smaller debts (Mahawyahrti and Budiasih, 2016). The greater the obligation will make the company's management difficult in making predictions of the company in the future. Companies that violate debt potentially face various possibilities, such as the possibility of accelerating maturity, increasing interest rates, and renegotiating debt periods (Hasty and Herawaty, 2017). The study results (Agustia and Suryani, 2018; Deviyanti and Sudana, 2018; Fandriani and Tunjung, 2019) found that Leverage had a positive effect on earnings management. While the research results from (Wijaya and Hendriyeni, 2021), Leverage does not affect earnings management.

The next dimension is litigation risk. Litigation risk is the risk of lawsuits that the company will receive from interested parties due to companies that deliberately cover up damaging information or carry out earnings management that can deceive users, which can cause losses to interested parties such as investors and creditors. (Kirana and Hasan, 2016). So it can be concluded that the higher the litigation risk, the smaller the earnings management. Research results from (Paramita et al., 2018; Darwis et al., 2020; Adani and Suryani, 2021) state that litigation risk has no significant effect on earnings management. Meanwhile, research results from (Kirana and Hasan, 2016; Tatar and Sujana, 2021) state that litigation risk does not affect earnings management.

Financial distress is also a dimension that affects earnings management. (Carolina et al., 2017) define financial distress as the stage of decline in financial conditions before bankruptcy or liquidation occurs. (Campa, 2019) suggests that earning management (earnings management) behavior will increase as the company's financial distress increases. The importance of providing information to investors about the company's performance so that profit reporting needs to be presented so that investors continue to assess that the company is in a good performance. The results of the study (Paramita et al., 2018; Aza et al., 2020; Krisnando and Damayanti, 2021) found that financial distress had an effect on earnings management. Meanwhile, the research results (Chamberlain et al., 2014; Melinda, 2019) state that financial distress has no significant effect on earnings management.

This study focuses on companies in the transportation sector; the reason for choosing the transportation sector is because the transportation sector is one of the sub-sectors of the infrastructure sector on the Indonesia Stock Exchange (IDX). Infrastructure is one of the determinants of economic development, which is as essential as other general production factors such as capital and labor. The transportation sector in Indonesia, both as infrastructure and as services, is the main artery of economic activity, which will determine the level of competitive advantage of an economy. The availability of adequate and effective infrastructure and facilities and the growth of efficient and highly competitive service industry in every transportation sector, whether land, sea, or air, will determine the speed of Indonesia's economic growth in overcoming increasingly fierce and tough global competition. This study aims to examine how accounting conservatism, Leverage, litigation risk, and financial distress influence earnings management.

\section{THEORITICAL REVIEW}

Currently, the impact of globalization is increasingly complex, affecting the increase in the economic growth of a country so that it requires support from the development of the 
business world (Cavanagh, 2004). Every business requires additional capital from outside the business for its survival. This has logical consequences for the emergence of intense competition between companies to compete to make investors interested in investing their capital (Mügge, 2010). In this case, the company must demonstrate excellent and healthy practices in providing information in the company's financial statements and avoid ways to generate quick profits by prioritizing the company's survival and the interests of stakeholders in a company (Ahmad et al., 2018).

Each company's financial statements have specific criteria that align with established policies (Amin and Anwar, 2020). State-Owned Enterprises are companies whose shares are owned mainly by the public through the stock exchange. The company is required to present its financial statements following the requirements set by the competent organization in Indonesia, namely the OJK (Financial Services Authority). Submission of this financial statement information must be made to meet the needs of external and internal parties (Sriwedari, 2012). The purpose of financial statements is to provide helpful information to assess management's ability to use resources effectively to achieve the company's main objectives (Pongoh, 2013). The financial statements consist of statements of financial position, income statements, statements of changes in equity, statements of cash flows, and notes to financial statements. In general, all financial statements are essential and needed in decision-making. However, most users of financial statements are more focused on the profit information contained in the income statement without paying attention to the procedures used to generate the profit or loss (Mahardini and Juwita, 2018).

The income statement contains profit information that is useful for users of financial statement information to determine the ability and financial performance of the company. The income statement provides the information needed by shareholders and potential investors to invest their funds (Rahim et al., 2020). The income statement is a report that measures the success of the company's operations over a certain period. Profit information in financial statements is the leading information in making investment decisions (Arsyad et al., 2021). Earnings information is often the target of engineering through opportunistic actions of management to maximize their satisfaction in manipulating financial statements to attract potential investors (Mahardini and Juwita, 2018).

Until now, financial reports have become a central issue as a source of manipulation of information that can harm parties with interest in the company (Hutton et al., 2009). Such self-interested actions are carried out by choosing specific accounting policies (Hasanuddin et al., 2021). So that profits can be regulated, increased, or decreased according to their wishes (Octaviany, 2017). Earnings management is used to influence the income level at a particular time for the benefit of management and stakeholders (Manggau, 2017). Earnings management occurs when managers use their judgment in financial reporting and transaction structures to modify financial statements. When management is not successful in achieving its profit target, management will modify its reporting by selecting and applying accounting methods that can show better profit achievement to show good company performance.

Recently, an exciting earnings management issue is the service company Garuda Indonesia, which manipulated the 2018 financial statements. This issue was finally known to the public in April 2019 because it not only covered the previous year's losses but also generated a net profit of Rp 11.33 billion or US\$ 8.0984 million. Fortunately, the company is polished. The violation in this financial report began with a cooperation agreement worth 
3.41 trillion rupiahs reached with PT Mahata Aero Technology in 2018, and a net profit was obtained. If there is no record of agreement revenue, the company must suffer a loss (www.cnnindonesia.com, 2019). Earnings management is suspected to arise or be carried out by managers or financial statement preparers in the financial reporting process of a company because they expect a benefit from these actions. Earnings management is interesting to study because it can describe the behavior of managers in reporting their business activities in a certain period, namely the possibility of the emergence of specific motivations that encourage them to regulate the reported financial data.

The dimensions of earnings management in this study include accounting conservatism, Leverage, litigation risk, and financial distress. The principle of conservatism is a principle which implies that the lowest value of assets and income and the highest value of liabilities and expenses should be selected for reporting (Utama and Titik, 2018). Therefore, the principle of conservatism requires that accountants display a generally pessimistic attitude when choosing accounting techniques for financial reporting.

Conservatism in accounting leads to higher quality returns because this principle prevents companies from overestimating profits and helps users of financial statements by presenting unbiased, overpriced profits and assets (Alfin et al., 2020). The results in the financial statements can explain a company's performance because performance is one of the crucial factors that indicate the effectiveness and efficiency of an organization in achieving its goals. The implication of a conservative approach is the choice of a lowerincome and asset accounting method or a higher statement of expenses and liabilities (Wakil, 2014).

The choice of a conservative method in financial statements makes managers think more carefully and choose to manage earnings with a pattern of lowering profits (income decreasing). High conservative accounting in making financial reports will hinder management in increasing retained earnings (Indriani and Amalia, 2019). The research results from (Alfin et al., 2020) and Gojaya et al., 2020) state that accounting conservatism affects earnings management. While the results of research from (Delhosh and Sadeghi, 2017) and (Ongki and Pangestu, 2018) state that accounting conservatism does not affect earnings management.

The next factor is Leverage, a loan provided to the company, while the interest charged is based on the lender's assessment of the company's risk (Firnanti, 2017). Leverage is the level of securities with debt used in a company's capital structure. Leverage is a ratio used to measure how the company is financed by debt (Fantazzini and Figini, 2009). Acceleration of maturity increased interest rates, and renegotiation of debt periods are consequences that can occur if the company violates the debt contract (Hasty \& Herawaty, 2017). Debt can improve earnings management when companies want to reduce the possibility of violating debt agreements and increase the company's bargaining position during debt negotiations (Utari and Sari, 2016).

Leverage shows how much the company's assets are financed by debt which can be measured by comparing total debt with total assets. Financial Leverage is the use of sources of funds that have a fixed burden, hoping that it will provide greater additional profits so that shareholder profits increase (Sutama and Lisa, 2018). Companies with large debts tend to violate debt agreements compared to companies with smaller debts (Mahawyahrti and Budiasih, 2016). The greater the obligation will make the company's management difficult in making predictions of the company in the future. Companies that violate debt potentially 
face various possibilities, such as the possibility of accelerating maturity, increasing interest rates, and renegotiating debt periods (Hasty and Herawaty, 2017). The study results (Agustia and Suryani, 2018; Deviyanti and Sudana, 2018; Fandriani and Tunjung, 2019) found that Leverage had a positive effect on earnings management. While the research results from (Wijaya and Hendriyeni, 2021), Leverage does not affect earnings management.

The next dimension is litigation risk. Litigation risk is the risk of lawsuits that the company will receive from interested parties due to companies that deliberately cover up damaging information or carry out earnings management that can deceive users, which can cause losses to interested parties such as investors and creditors. (Kirana and Hasan, 2016). So it can be concluded that the higher the litigation risk, the smaller the earnings management. Research results from (Paramita et al., 2018; Darwis et al., 2020; Adani and Suryani, 2021) state that litigation risk has no significant effect on earnings management. Meanwhile, research results from (Kirana and Hasan, 2016; Tatar and Sujana, 2021) state that litigation risk does not affect earnings management.

Financial distress is also a dimension that affects earnings management. (Carolina et al., 2017) define financial distress as the stage of decline in financial conditions before bankruptcy or liquidation occurs. (Campa, 2019) suggests that earning management (earnings management) behavior will increase as the company's financial distress increases. The importance of providing information to investors about the company's performance so that profit reporting needs to be presented so that investors continue to assess that the company is in a good performance. The results of the study (Paramita et al., 2018; Aza et al., 2020; Krisnando and Damayanti, 2021) found that financial distress had an effect on earnings management. Meanwhile, the research results (Chamberlain et al., 2014; Melinda, 2019) state that financial distress has no significant effect on earnings management.

Ross first developed this signal theory in 1977. In building the signal theory based on the information asymmetry between management information (well-informed) and information from shareholders (poo informed). This theory is based on the idea that management will provide information to investors or shareholders when they get good information related to the company, such as increasing company value (Mayogi and Fidiana, 2016). Signal theory explains how investors have the same information about the company's prospects, but the manager (the company) has more information. This is called information asymmetry, and it has an important impact on the optimal capital structure. Information published as an announcement will signal investors to make decisions.

Companies with high values will signal their financial policies so that they are not the same as companies with low values. The signal is a process that takes the form of deadweight costing, which aims to convince investors about the company's value. (Mahawyahrti and Budiasih, 2016) argue that the company's impetus to provide information is information asymmetry between the company and outside parties. Therefore, the manager must be obliged to signal the company's condition to the owner. Information received by investors can be in the form of a sound signal (good news) or a wrong signal (bad news). A good signal, if the company's reported profit increases and vice versa if the company's reported profit decreases, it is a wrong signal for investors (Megasari et al., 2018). Information is an essential element for investors or business people because the information provides information, notes, or a description of the company for the past, current, and future conditions for the continuity of the company's business. Investors in the capital market need 
complete, relevant, accurate, and timely information as an analytical tool for making investment decisions.

Conservatism in accounting states that if there are several accounting alternatives, the alternative that should be chosen is the alternative that is least likely to report assets or income more significant than it should be (Chen et al., 2007). In contrast to conservatism, when using the principle of optimism, the company will report that earnings tend to be higher. Companies that use this concept are usually more daring in taking risks but are less able to anticipate uncertainties that may occur in the future. The choice of the conservatism method in the financial statements tends to make managerial thinking more careful and choose to manage earnings with a pattern of lowering profits (income decreasing). High accounting conservatism in making financial statements will prevent management from increasing retained earnings. This shows a significant influence between accounting conservatism on earnings management (Indriani and Amalia, 2019). The results of the study (Alfin et al., 2020; Gojaya et al., 2020) state that accounting conservatism affects earnings management. Meanwhile, the research results (Delkhosh and Sadeghi, 2017; Ongki and Pangestu, 2018) state that accounting conservatism does not affect earnings management.

H1: Accounting conservatism has an effect on earnings management.

States that leverage is a loan provided to the company, while the interest charged is based on the lender's assessment of the company's risk. Leverage shows how much the level of assets financed by debt. The level of leverage can be known by comparing total debt with total assets. (Firnanti, 2017) states that companies with a higher leverage ratio have a higher debt risk than the value of their assets, which will tend to take earnings management actions within the company. Companies with high leverage tend to manage their profits compared to companies with lower leverage values. The study results (Agustia and Suryani, 2018; Deviyanti and Sudana, 2018; Fandriani and Tunjung, 2019) found that leverage had a positive effect on earnings management. At the same time, the results of research (Wijaya and Hendriyeni, 2021) leverage does not affect earnings management.

H2: Leverage has a significant effect on earnings management.

Litigation risk is the risk of lawsuits received by the company from interested parties due to companies that deliberately cover up negative information or by carrying out earnings management that can deceive users, which can cause losses to interested parties such as investors and creditors. (Kirana and Hasan, 2016). So it can be concluded that the higher the litigation risk, the smaller the earnings management. Research results from (Paramita et al., 2018; Darwis et al., 2020; Adani and Suryani, 2021) state that litigation risk has no significant effect on earnings management. States that litigation risk affects earnings management. Meanwhile, research results (Kirana and Hasan, 2016; Tatar and Sujana, 2021) state that litigation risk does not affect earnings management.

H3: Litigation risk has a significant effect on earnings management.

(Kisman and Krisandi, 2019) define financial distress as the stage of declining financial conditions before bankruptcy or liquidation occurs. Financial distress begins with 
the inability to fulfill its obligations, especially short-term obligations, including liquidity obligations and obligations in the solvency category. (Rezende et al., 2017) stated that financial distress is the company's inability to fulfill its obligations; in other words, the company experiences insolvency. Financial distress is a severe problem for companies because, if left unchecked, it can lead to bankruptcy or liquidation, so this can encourage company managers to carry out earnings management. Financial distress is reflected in the inability or unavailability of funds to pay obligations that have matured (Krisnando and Damayanti, 2021). (Setiany, 2021) suggests that earnings management behavior will increase along with the company's financial distress. The importance of providing information to investors about the company's performance so that profit reporting needs to be presented so that investors continue to assess that the company is in a good performance. When a company experiences funding constraints (financial distress), managers tend to carry out earnings management to continue giving a good signal by displaying short-term earnings performance, which always increases even though the company is in trouble (Ariesanti, 2015). The results of the study (Paramita et al., 2018; Aza et al., 2020; Krisnando and Damayanti, 2021) found that financial distress had an effect on earnings management. Meanwhile, the research results (Chamberlain et al., 2014; Melinda, 2019) state that financial distress has no significant effect on earnings management.

H4: Financial distress has a significant effect on earnings management.

\section{METHODS}

This research includes quantitative causal research. The population of this study is transportation service companies listed on the Indonesia Stock Exchange (IDX) in the 20172020 period. The total population of transportation service companies based on the 2020 BEI factbook is 42 . In this study, the sampling technique used is purposive sampling. The purposive sampling technique is a technique of determining the sample by considering it.

Table 1. Sampling Criteria

\begin{tabular}{llc}
\hline No. & \multicolumn{1}{c}{ Description } & Number of Companies \\
\hline 1. & $\begin{array}{l}\text { All transportation service companies listed on the Indonesia } \\
\text { Stock Exchange for the 2017-2020 period. } \\
\text { Transportation service companies that experienced delisting } \\
\text { during the 2017-2020 period }\end{array}$ & 42 \\
Manufacturing companies that do not publish complete \\
annual financial reports as of December 31 and
\end{tabular}




\section{RESULTS}

The results of the data normality test in this study used a normal probability plot graph as presented in Figure 1.

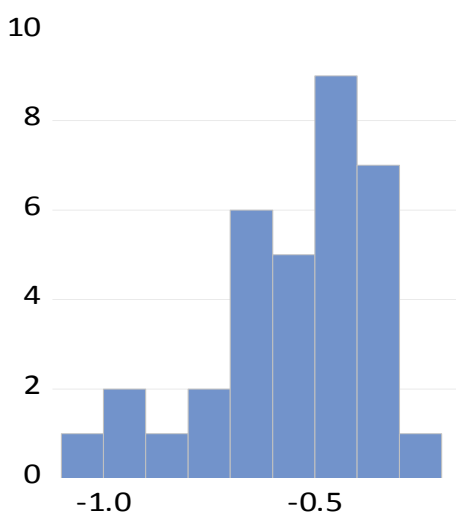

$-1.0$

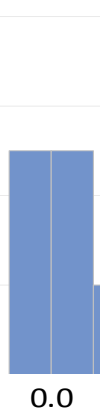

0.0

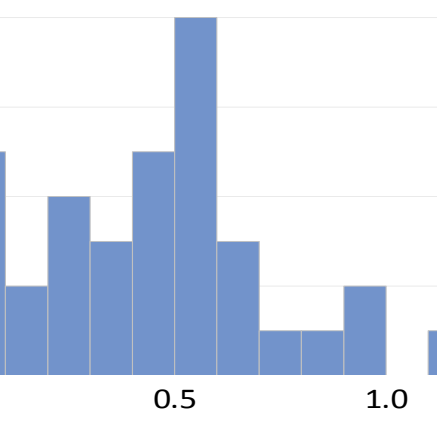

1.0

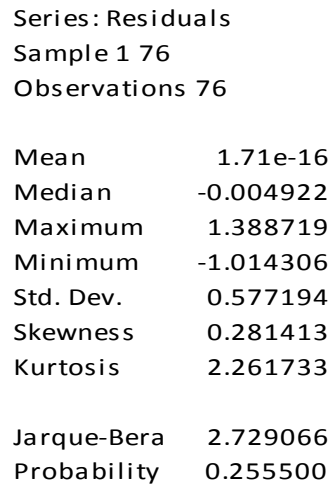

Figure 1. Normality Test Results

Source : Output Eviews V.12 (2021)

Figure 1 shows the Jarque-Bera value of 2.729 and a significance of 0.2555 or $25.50 \%$ $>5 \%$ significance level, meaning that the research variables are normally distributed. To ensure that the estimated data are free from autocorrelation, this study uses the BruschGodfrey method as presented in table 2 .

Table 2. Autocorrelation Test Results

\begin{tabular}{llc}
\hline No & Info & Breusch-Godfrey test \\
\hline 1 & F. Statistik & 0,7883 \\
& Prob. F & 0,5366 \\
2 & Obs* R-Square & 3,2317 \\
& Prob. Chi-Square & 0,5198 \\
\hline
\end{tabular}

Source : Output Eviews V.12 (2021)

In table 2, it can be seen that the value of Prob. $F$ is equal to 0.2795 and is greater than the 5\% significance level. This shows that in this study there is no autocorrelation. Furthermore, the results of the heteroscedasticity test were carried out to see whether there were disturbances that appeared in the regression function. The results of the heteroscedasticity test can be seen in table 3 .

Table 3. Heteroskedasticity Test Glejser Results

\begin{tabular}{llc}
\hline No & Info & Glejser Test \\
\hline 1 & F. Statistik & 1,7390 \\
& Prob. F & 0,1510 \\
2 & Obs* R-Square & 6,7814 \\
& Prob. Chi-Square & 0,1479 \\
\hline
\end{tabular}

Source : Output Eviews V.12 (2021) 
Based on table 3, the value of Prob. From the F-count and Chi-Square count of all tests is greater than the significance value of 5\%, then there is no heteroscedasticity in the equation model. Furthermore, the multicollinearity test in this study used the Pearson Correlation as shown in table 4.

Table 4. Multikolinearitas Result

\begin{tabular}{llc}
\hline No & Auxiliary & Variance Inflation Factors (VIF). \\
\hline 1 & Accounting Conservatism & 0,462 \\
2 & Leverage & 0,510 \\
3 & Litigation Risk & 0,359 \\
4 & Financial Distress & 0,210 \\
\hline Source : Output Eviews V.12 (2021)
\end{tabular}

Based on table 4, the coefficient value between variables is less than 0.9 ; so the data in this study indicate that there is no multicollinearity problem.

Table 5. Coefficient of Determination

\begin{tabular}{lc}
\hline Description & Coefficient of Determination \\
\hline R Squared & 0,341 \\
Adj. R-Squared & 0,303 \\
\hline
\end{tabular}

Source : Output Eviews V.12 (2021)

Based on table 5, the R-Square number is 0.341 while the Adjust R-Square value is 0.303 . The R-Square result of $30.30 \%$ shows that the variables of accounting conservatism, leverage, litigation risk and financial distress have an effect on earnings management.

Table 6. Partial Test Results

\begin{tabular}{lccc}
\hline \multicolumn{1}{c}{ Variable } & B & t & Sig. \\
\hline Contant & 0,0210 & 1,4014 & 0.165 \\
Accounting Conservatism & 0.0461 & 2,5878 & 0.005 \\
Leverage & 0,0594 & 3,4871 & 0.002 \\
Litigation Risk & 0,0015 & 0,4629 & 0,644 \\
Financial Distress & 0,0007 & 0,1373 & 0.891 \\
\hline
\end{tabular}

Source : Output Eviews V.12 (2021)

Based on table 6 , the panel data regression equation is obtained as follows:

Earnings management $=0,0210+0,0461$ Accounting Conservatism $+0,0594$ Leverage $+0,0015$ Litigation Risk + 0,0007 Financial Distress + e

The coefficient of the accounting conservatism variable is 0.0461 with a positive direction, meaning that if there is accounting conservatism, earnings management will increase by 0.0461 . The leverage variable is 0.0594 with a positive direction, meaning that if there is an increase in leverage, earnings management will increase by 0.0594 . The coefficient of the litigation risk variable is 0.0015 with a positive direction, meaning that if 
there is an increase in litigation risk, earnings management will increase by 0.0015 . The coefficient of the financial distress variable is 0.0007 with a positive direction, meaning that if there is an increase in financial distress, earnings management will increase by 0.0007 .

\section{DISCUSSION}

The results of testing the first hypothesis indicate that accounting conservatism has a significant effect on earnings management. This shows that the first hypothesis (H1) proposed is accepted. These results illustrate that prudence in reporting company finances can lead managers to report lower earnings and assets or higher costs and debt. The high accounting conservatism in financial statements will prevent management from increasing retained earnings so that it encourages managers to take earnings management actions, where managers can manipulate financial data, mainly the profits earned by the company. The results of this study support the signal theory, which explains the principle of accounting conservatism in financial statements as a positive signal given by managers to external parties regarding the quality of company earnings. The positive coefficient value indicates that the more conservative the company is in its financial reporting, the more earnings management actions can take, namely, lowering profits. This is because the method used in conservatism is the same as earnings management measures (decreasing income), reporting lower profits in the current period to get more significant profits in future periods. Accounting conservatism can affect earnings management because, in financial reporting, there are several characteristics of managers who instinctively use the principles of accounting conservatism in providing managerial decisions that impact earnings management actions (Soraya, 2014; Alfin et al., 2020; Gojaya et al., 2020). The opportunistic behavior of managers influences company managers who choose conservative or optimistic accounting to maximize profits to manage earnings to maximize their interests. In essence, the precautionary method in financial reporting is the same as earnings management actions with a pattern of lowering profits. The purpose of these efforts is to regulate the current period's profit to be lower than the actual profit by recognizing and recording more quickly and recognizing expenses.

Moreover, record revenue more slowly. In contrast (Delkhosh and Sadeghi, 2017) and (Ongki and Pangestu, 2018) found that conservatism can reduce managers' actions in accounting conservatism. The higher the role of accounting conservatism, the less opportunity for managers to manipulate or overstate financial statements.

The results of testing the second hypothesis (H2) indicate that leverage significantly affects earnings management. These results indicate that (H2) is accepted. The results of this test illustrate that leverage must be analyzed to see how well the funds are handled; the mix of short-term and long-term funds obtained from outside must be under company goals and policies. If the handling of these funds is not carried out properly, then financial leverage can trigger the management to carry out earnings management. The results support the agency theory, which explains that the closer a company is to accounting-based debt covenant violations, the more likely it is for company managers to choose accounting procedures that transfer reported earnings from future periods to the current period. Efforts to get a good assessment from investors on debt agreements make the management practice earnings management. The study results (Agustia and Suryani, 2018; Deviyanti and Sudana, 2018; Fandriani and Tunjung, 2019) found that leverage had a positive effect on earnings 
management. Companies with high leverage tend to manage their profits compared to companies with lower leverage values. In contrast to the results (Wijaya and Hendriyeni, 2021), leverage does not affect earnings management. The results of this study explain that the nominal amount of debt owed by a company is not one of the reasons or impetus for the management to practice earnings management.

The results of testing the third hypothesis (H3) show that litigation risk has no significant effect on earnings management. These results indicate that hypothesis $3(\mathrm{H} 3)$ is rejected. This is because litigation is a risk that can incur high costs due to dealing with legal issues. Managers will avoid losses due to litigation by reporting financially conservatively because earnings that are too high have the potential for higher litigation risk. Thus, most companies will report financially according to the actual situation. In addition, every company is now required to have an auditor who audits the company's financial statements so that litigation risk does not affect the existence of earnings management (Kirana and Hasan, 2016). The results of this study support agency problems that may occur due to information asymmetry. An imbalance of information can occur due to a lack of information obtained by one of the parties. As a party that plays a direct role in operational activities in the company, it allows managers to have more comprehensive information than shareholders so that shareholders who have little information will have difficulty controlling the company managed by the manager. The difference in information can be an opportunity for agents to manipulate financial information without being known by the principal about the absolute truth. Manipulation of financial information can be detrimental to several interested parties, so efforts are needed to avoid this. Litigation risk can occur because of a conflict of interest between the agent and the principal. The study results (Darwis et al., 2020; Adani and Suryani, 2021) support the results of this study which found litigation risk had no significant effect on earnings management. So it can be concluded that the higher the litigation risk, the smaller the earnings management. However, it is different from the research results from (Tatar and Sujana, 2021), which states that litigation risk affects earnings management. The higher the level of corporate litigation risk, the management will try to cover it up by manipulating financial statements to make it look suitable for interested parties such as investors and potential investors to continue to believe and be interested in investing in the company.

The results of testing the fourth hypothesis (H4) indicate that financial distress has no significant effect on earnings management. These results indicate that the fourth hypothesis (H4) proposed is rejected. This can happen because the company's management requires immediate actions when the company is in a state of difficulty. Thus, when the company is in financial difficulty, its management does not overcome it by carrying out accrual earnings management. The company's management focuses more on the financial problems experienced by the company and prefers to take actions that have tangible results so that financial difficulties can be resolved and do not lead to company bankruptcy. The results of this study support the signal theory, which explains the importance of providing information to investors about the company's performance so that profit reporting needs to be presented so that investors continue to judge that the company is in a good performance. When a company experiences funding constraints (financial distress), managers tend to carry out earnings management to continue to give a good signal by displaying short-term earnings performance, which is constantly increasing even though the company's condition is in trouble. The results of this study support (Chamberlain et al., 2014; Melinda, 2019) finding 
that financial distress has no significant effect on earnings management. Companies experiencing financial difficulties do not practice accrual earnings management either in the short or long term but prefer to do natural earnings management because it is easier to implement, provides more tangible results, and is more difficult to detect by auditors. Contrary to the findings (Paramita et al., 2018), (Aza et al., 2020) and (Krisnando and Damayanti, 2021) find that financial distress affects earnings management. The higher the company's financial distress level, the higher the earnings management of banking companies on the IDX. Financial distress is reflected in the inability or unavailability of funds to pay obligations that have matured (Gupta and Suartana, 2018).

\section{CONCLUSION}

Based on testing the data in this study, the earnings management actions of transportation service companies listed on the Indonesia Stock Exchange (IDX) in the 20172020 period were not affected by litigation risk and financial distress. However, they were influenced by accounting conservatism and leverage. We suggest that further researchers add other variables that might affect earnings management, such as free cash flow. Further researchers are also advised to use a different measurement scale and company sector. Companies must pay more attention to monitoring activities carried out by company owners and investors as company shareholders. Monitoring activities will be a solution for companies to prevent earnings management from occurring in the company. Investors who are active in monitoring will reveal more earnings management practices in a company.

\section{REFERENCES}

Adani, I. T., dan Suryani, E. (2021). Pengaruh Kompensasi Eksekutif, Risiko Litigasi, Dan Profitabilitas Terhadap Manajemen Laba (studi Pada Perusahaan Sub Sektor Properti Dan Real Estate Yang Terdaftar Di Bursa Efek Indonesia Periode 2016-2019). eProceedings of Management, 8(5).

Agustia, Y. P., dan Suryani, E. (2018). Pengaruh ukuran perusahaan, umur perusahaan, leverage, dan profitabilitas terhadap manajemen laba (Studi Pada Perusahaan Pertambangan yang Terdaftar di Bursa Efek Indonesia Periode 2014-2016). Jurnal Aset (Akuntansi Riset), 10(1), 71-82. https://doi.org/10.17509/jaset.v10i1.12571.

Ahmad, H., Mappatompo, A., and Muslim, M. (2018). Capital Ownership Structure And Decision On Fi-financial Market Reaction And Corporate Value. International Journal of Innovative Science and Re-search Technology, 3(9), 395-406.

Alfin, M., Amin, M., dan Junaidi, J. (2020). Pengaruh Konservatisme Akuntansi Terhadap Relevansi Nilai Laporan Keuangan, Manajemen Laba Dengan Kepemilikan Manajerial Sebagai Variabel Moderasi (Studi Empiris Pada Perusahaan Manufaktur Yang Listing Di Bei Tahun 2016-2018). Jurnal Ilmiah Riset Akuntansi, 9(12).

Amin, A., dan Anwar, A. (2020). Dimensi Karakteristik Laporan Keuangan Pemerintah. Jurnal Akuntansi, 10(3), 223-230. https://doi.org/10.33369/j.akuntansi.10.3.223-230.

Ariesanti, D. D. (2015). Pengaruh Mekanisme Good Corporate Governance Dan Financial Distress Terhadap Manajemen Laba (Studi Kasus Pada Perusahaan Perbankan Yang Terdaftar Di Bursa Efek Indonesia Periode 2009-2014). Implementation Science, 39(1), 1-15. 
Beatty, A., Weber, J., and Yu, J. J. (2008). Conservatism and debt. Journal of Accounting and Economics, 45(2-3), 154-174.

Campa, D. (2019). Earnings management strategies during financial difficulties: A comparison between listed and unlisted French companies. Research in International Business and Finance, 50, 457-471.

Carolina, V., Marpaung, E. I., dan Pratama, D. (2017). Analisis Rasio Keuangan untuk Memprediksi Kondisi Financial Distress (Studi Empiris pada Perusahaan Manufaktur yang Terdaftar di Bursa Efek Indonesia Periode 2014-2015). Jurnal Akuntansi, 9(2).

Cavanagh, J. (2004). Alternatives to economic globalization: A better world is possible. Berrett-Koehler Publishers.

Chamberlain, T. W., Butt, U. R., and Sarkar, S. (2014). Accruals and real earnings management around debt covenant violations. International Advances in Economic Research, 20(1), 119-121.

Darwis, H., Mahdi, S. A., dan Maksud, F. D. (2020). Pengaruh Fleksibilitas Akuntansi, Tingkat Pengungkapan Laporan Keuangan dan Risiko Litigasi Terhadap Real Earning Management dengan Kualitas Audit Sebagai Variabel Pemoderasi. Jurnal Ilmiah Akuntansi Peradaban, 6(1).

Delkhosh, M., and Sadeghi, M. (2017). The effect of accounting conservatism and earnings management on earnings quality. International Journal of Accounting and Economics Studies, 5(2), 157-162.

Deviyanti, N. W. T., dan Sudana, I. P. (2018). Pengaruh Bonus, Ukuran Perusahaan, dan Leverage pada Manajemen Laba. E-Jurnal Akuntansi Universitas Udayana, 23(2), $1415-1441$.

Dewi, I. G. A. R., Rahindayati, N. M., dan Permanakusuma, M. L. (2019). Pengaruh Faktor Internal Perusahaan Terhadap Manajemen Laba. JSAM (Jurnal Sains, Akuntansi Dan Manajemen), 1(4), 550-575.

Fandriani, V., dan Tunjung, H. (2019). Pengaruh Profitabilitas, Leverage, Ukuran Perusahaan, Dan Kualitas Audit Terhadap Manajemen Laba. Jurnal Paradigma Akuntansi, 1(2), 505-514.

Fantazzini, D., \& Figini, S. (2009). Default forecasting for small-medium enterprises: Does heterogeneity matter? International Journal of Risk Assessment and Management, 11(1-2), 138-163.

Firnanti, F. (2017). Pengaruh corporate governance, dan faktor-faktor lainnya terhadap manajemen laba. Jurnal Bisnis Dan Akuntansi, 19(1), 66-80.

Gojaya, A. A., Ulfah, Y. Y., dan Yanti, M. M. (2020). Pengaruh Kepemilikan Manajerial, Dewan Komisaris Independen, Komite Audit, Dan Konservatisme Akuntansi Terhadap Manajemen Laba Pada Perusahaan Manufaktur Yang Terdaftar Di Bursa Efek Indonesia. Jurnal Ilmu Akuntansi Mulawarman (JIAM), 4(2).

Gupta, A. T., dan Suartana, I. W. (2018). Pengaruh financial distress dan kualitas corporate governance pada manajemen laba. E-Jurnal Akuntansi Universitas Udayana, 23(2), 26.

Hasanuddin, R., Darman, D., Taufan, M. Y., Salim, A., Muslim, M., and Putra, A. H. P. K. (2021). The Effect of Firm Size, Debt, Current Ratio, and Investment Opportunity Set on Earnings Quality: An Empirical Study in Indonesia. The Journal of Asian Finance, Economics and Business, 8(6), 179-188. 
Hasty, A. D., dan Herawaty, V. (2017). Pengaruh struktur kepemilikan, leverage, profitabilitas dan kebijakan dividen terhadap manajemen laba dengan kualitas audit sebagai variabel moderasi. Media Riset Akuntansi, Auditing \& Informasi, 17(1), 116.

Indriani, R., dan Amalia, R. M. (2019). Efek Negatif Konservatisme terhadap Reaksi Pasar. Jurnal Akuntansi Multiparadigma, 10(2), 399-412.

Kirana, R., dan Hasan, A. (2016). Pengaruh Tingkat Pengungkapan Laporan Keuangan, Kecakapan Manajerial Dan Risiko Litigasi Terhadap Manajemen Laba Dengan Kualitas Audit Sebagai Variabel Pemoderasi (Studi Empiris Perusahaan Manufaktur Di BEI). Jurnal Akuntansi (Media Riset Akuntansi \& Keuangan), 4(2), 189-205.

Kisman, Z., and Krisandi, D. (2019). How to predict financial distress in the wholesale sector: Lesson from Indonesian Stock Exchange. Journal of Economics and Business, 2(3), 569-585.

Krisnando, K., dan Damayanti, S. (2021). Pengaruh Financial Distress, Komite Audit, dan Ukuran Perusahaan Terhadap Manajemen Laba. Jurnal STEI Ekonomi, 30(01), 101113.

Mahardini, N. Y., dan Juwita, N. (2018). Menguji Dampak Net Profit Margin, Debt To Equity Ratio, Dan Retur on Asset Pada Praktik Perataan Laba. JAK (Jurnal Akuntansi) Kajian Ilmiah Akuntansi, 5(2), 87-95.

Mahawyahrti, P. T., dan Budiasih, G. N. (2016). Asimetri informasi, leverage, dan ukuran perusahaan pada manajemen laba. Jurnal Ilmiah Akuntansi Dan Bisnis, 11(2), 100110.

Manggau, A. W. (2017). Pengaruh asimetri informasi dan ukuran perusahaan terhadap manajemen laba pada perusahaan pertambangan yang terdapat di bursa efek indonesia. AKUNTABEL, 13(2), 103-114.

Mayogi, D. G., dan Fidiana, F. (2016). Pengaruh Profitabilitas, Kebijakan Dividen Dan Kebijakan Utang Terhadap Nilai Perusahaan. Jurnal Ilmu Dan Riset Akuntansi (JIRA), 5(1).

Megasari AWS, R., Surtikanti, S., dan Darmansyah, D. (2018). Determinan Pertumbuhan Laba Perusahaan Manufaktur Di Bursa Efek Indonesia . Jurnal Riset Akuntansi \& Perpajakan (JRAP), 5(02), 166-174. https://doi.org/10.35838/jrap.2018.005.02.15

Melinda, W. (2019). Faktor Yang Mempengaruhi Manajemen Labaperusahaan Manufaktur Yang Terdaftar Di Bei. Jurnal Paradigma Akuntansi, 1(2), 452-459.

Mügge, D. (2010). Widen the market, narrow the competition: banker interests and the making of a European capital market. ECPR Press.

Octaviany, F. (2017). Pengaruh Asimetri Informasi, Tingkat Leverage, dan Ukuran Perusahaan terhadap Manajemen Laba Dalam Laporan Tahunan Perusahaan Indeks LQ-45 di Bursa Efek Indonesia. Jurnal Lentera Akuntansi, 1(1), 21-37.

Ongki, S., dan Pangestu, S. (2018). Determinan dan konsekuensi konservatisme akuntansi: mekanisme corporate governance dan manajemen laba. BALANCE: Jurnal Akuntansi, Auditing Dan Keuangan, 15(1), 90-112.

Paramita, N. N. E. Y., Edy Sujana, S. E., Herawati, N. T (2018). Pengaruh financial distress, risiko litigasi dan pengungkapan corporate social responsibility terhadap manajemen laba (studi empiris pada perusahaan manufaktur yang terdaftar di bursa efek Indonesia periode 2014-2016). JIMAT (Jurnal Ilmiah Mahasiswa Akuntansi) Undiksha, 8(2). 
Pongoh, M. (2013). Analisis Laporan Keuangan untuk Menilai Kinerja Keuangan PT. Bumi Resources Tbk. Jurnal EMBA: Jurnal Riset Ekonomi, Manajemen, Bisnis Dan Akuntansi, 1(3).

Prastiti, A., dan Meiranto, W. (2013). Pengaruh karakteristik dewan komisaris dan komite audit terhadap manajemen laba. Diponegoro Journal of Accounting, 72-83.

Putri, Y. K. W., and Sujana, I. K. (2018). The influence of bid-ask spread and leverage on earnings management with good corporate governance as moderating variable. International Research Journal of Management, IT and Social Sciences, 5(3), 8-21.

Rahim, S., Ahmad, H., Muslim, M., and Nursadirah, A. (2020). Disclosure of Local Government Financial Statements in South Sulawesi. In Brawijaya International Conference on Multidisciplinary Sciences and Technology (BICMST 2020) (pp. 1-6). Atlantis Press.

Rezende, F. F., Montezano, R. M. da S., Oliveira, F. N. de, and Lameira, V. de J. (2017). Predicting financial distress in publicly-traded companies. Revista Contabilidade \& Finanças, 28, 390-406.

Setiany, E. (2021). The Effect of Investment, Free Cash Flow, Earnings Management, and Interest Coverage Ratio on Financial Distress. Journal of Social Science, 2(1), 67-73.

Soraya, I. (2014). Pengaruh Konservatisma Akuntansi Terhadap Manajemen Laba Dengan Kepemilikan Manajerial Sebagai Variabel Pemoderasi. Diponegoro Journal of Accounting, 452-462.

Sriwedari, T. (2012). Mekanisme good corporate governance, manajemen laba dan kinerja keuangan perusahaan manufaktur di Bursa Efek Indonesia. Jurnal Mediasi, 4(01), 7888.

Sutama, D., dan Lisa, E. (2018). Pengaruh leverage dan profitabilitas terhadap nilai perusahaan. JSMA (Jurnal Sains Manajemen Dan Akuntansi), 10(1), 21-39.

Tatar, P. W. G., dan Sujana, E. (2021). Pengaruh Kepemilikan Manajerial, Employee Diff dan Risiko Litigasi Terhadap Manajemen Laba Pada Perusahaan Manufaktur di Indonesia. Jurnal Akuntansi Profesi, 12(1), 10-20.

Utama, E. P., dan Titik, F. (2018). Pengaruh Leverage, Ukuran Perusahaan, Kepemilikan Manajerial Dan Profitabilitas Terhadap Konservatisme Akuntansi (Studi Pada Subsektor Telekomunikasi Yang Terdaftar Di Bursa Efek Indonesia Periode 20112016). EProceedings of Management, 5(1).

Utari, N. P. L. A., dan Sari, M. M. R. (2016). Pengaruh asimetri informasi, leverage, kepemilikan manajerial dan kepemilikan institusional pada manajemen laba. E-Jurnal Akuntansi Universitas Udayana, 15(3), 1886-1914.

Wakil, G. (2014). Market-to-book ratio and conditional conservatism: firms' voluntary expensing of employee stock options. Accounting Research Journal.

Wijaya, P. M. N., dan Hendriyeni, N. S. (2021). FCF dan Leverage terhadap Manajemen Laba Dengan GCG sebagai Pemoderasi (Sektor Transportasi). Jurnal Akuntansi dan Manajemen, 18(02), 103-113. 